\title{
Molecular genetic variability of some deciduous fruit rootstocks in Egypt
}

\section{Safaa M. Saleh ${ }^{1}$, Nahla O.Ehsan ${ }^{1}$, Sayed Y.Mohamed ${ }^{2}$, and Thoria} R.Mohamed ${ }^{1}$.

${ }^{1}$ Botany Department, Faculty of women for Arts, Science and Education, Ain Shams University, Cairo, Egypt

${ }^{2}$ Horticulture Research Institute, Agriculture Research Center, Ministry of Agriculture Ministry, Giza.

\section{ABSTRACT}

The study was executed during two successive years (2016 and 2017) in the Orchard of Deciduous fruit department and Biotechnology Research lab of Horticulture Research Institute, Agriculture Research Center, Giza, Egypt. The aim of the work was using one year old plants of five and four seedy strains of Pear (Betulaefolia) and Peach (Mit-Ghamr) deciduous fruit rootstocks, where the study carried out to evaluate the molecular genetic variability between the two seedy strains rootstock respectively by using two molecular genetic markers, ISSR and SCoT based on PCR techniques to support the use of marker-assisted selection (MAS) for detection of a biotic and biotic stress in seedy strains.

Six and Ten primers were used with ISSR and SCoT molecular genetic markers had successfully generated reproducible polymorphic products to study the genetic variability between Betulaefolia and Mit-Ghamr rootstocks. Data cleared that high levels of polymorphism among the strains studied of each rootstock, where a total bands of five seedy strains of Betulaefolia rootstock with ISSR-SCOT primers were recorded 105 band (43-62 respectively), and the total monomorphic bands were 29 (11-18) added to total polymorphic bands was recorded 76 (32-44) with polymorphic percentage $(74.44 \%-71 \%)$ where the specific marker bands were 30 (13 -17) respectively. On the other hand, four seedy strains of MitGhamr rootstock with ISSR- SCOT primers data recorded 97 total bands as (31-66 respectively).

Corresponding author: safaaismael28@gmail.com 
These bands identified as 43 (14-29) monomorphic ones and 54 (17-37) polymorphic bands with polymorphic percentage were $(54.8 \%-56 \%)$ and the specific markers bands scored 40 (13-27).

Keywords: Seedy strains- Betulaefolia and Mit-Ghamr deciduous fruit

Rootstocks - ISSR and SCoT Molecular Markers.

\section{INTRODUCTION}

Peach and Pear from (Rosaceae family), their binomial name were (Prunus persica - Pyrus comunus) and they considered a highly demanded by Egyptian consumers. There are many peach varieties growing more widely now throughout the world، and Pear is one of the most important deciduous fruit trees all over the world, where it takes the second rank after apple in production. Rootstocks play an important role in Peach and Pear production, since, the proper choice of rootstock is as important as the choice of variety and site. This is true because the rootstock is involved in determining two key factors: the variety susceptibility to several serious diseases - added to the tree's performance in the climate and the orchard site.

Four and five strains of shoot tips and stem segments of young branches of peach var. Meet Ghamr rootstock and pear var. Betulaefolia with a chromosome number $2 \mathrm{n}=2 \mathrm{x}=16$ and Genome size of $265 \mathrm{Mb}$., and chromosome number $2 n=34$ and Genome size of $577 \mathrm{Mb}$. respectively. https://www.rosaceae.org/organism/Prunus/persica

These strains were selected after detection of salt stress genes using marking assistant selection (MAS) by BADH and Rubisco genes. Molecular markers are of interest to plant geneticists and breeders as a source of new genetic information on plant genomes and for use in trait selection.

Lisek and Rozpara (2010), Mohamed and El-Sharabasy (2009), Gihan et al., (2009), Abo Rekab et al., (2010), Gad and Mohamed (2012), Fathi et al., (2013), Ozyurt et.al.,(2013),Mohamed et al., (2015) and Khorshidi et al.,(2017) recorded that ISSR primers had successfully generated 
reproducible polymorphic products between pear, peach strains and Okinawa Rootstock, grape cultivars, date palm cultivars, some pinus species and apricot strains with a high levels of polymorphism among the studied cultivars and strains.

Start Codon Targeted (SCoT) polymorphic markers were used to assess genetic relationships among grape varieties, Cicer, Pear and Sweet potato, revealed start codon targeted polymorphism technique can be utilized to identify DNA polymorphisms and fingerprint cultivars in domesticated peanut reported that SCoT markers were more informative and the efficiency of SCOT for fingerprinting of varieties was more than other markers based on the average percentage polymorphism conducted to different references, Gorji et al., (2011), Xiong et al., (2011), Amirmoradi et al.,(2012),(Guo et al.,2012), Shahlaei et al.,(2014), Etminan et al., (2016) and Nair et al.,(2016). Mohamed et al.,(2017).

The objective of the study was to obtain further additional information about the genetic variability between five seedy strains of Betulaefolia rootstock also between four seedy strains of Mit-Ghamr rootstock by using ISSR and SCOT molecular genetic markers.

\section{MATERIALS AND METHODS}

\section{Plant Material}

This study were conducted for two years (2016 and 2017) in the orchard of Deciduous fruit Department and Biotechnology Research Lab of Horticulture Research Institute, Agriculture Research Center, Giza, Egypt. One year old plants of five seedy strains of Betulaefolia rootstock and four seedy strains of Mit-Ghamr rootstock were used obtained in spring-summer and autumn. After using a marker assisted selection (MAS) for detection of a biotic and biotic stress in seedy strains, the five pear strains were $(1,2,9,10$ and 11), and four peach strains selected with number (2, 3, 8 and 14) takes serial numbers (stl, II, III, IV and V) and (stl, II, III, and IV) respectively according to their bands intensity and abundance 


\section{DNA Extraction}

Freshly excised leaves for each seedy strains of Betulaefolia and MitGhamr rootstocks, frozen in liquid nitrogen and subsequently stored at -20 oC until processed, were collected from the orchard of Deciduous fruit department, Horticulture Research Institute, Agriculture Research Center. Genomic DNA was extracted by DNeasy plant mini kit (Qiagen) with the enclosed manual. DNA quality was examined by electrophoresis $1 \%$ agarose and DNA concentration was quantified by means of calibration dependence was measured by photo Capt Mw v 3.0 software. For ISSR and SCoT analysis, aliquots of $10 \mathrm{ng} / \mathrm{ul}$ were prepared and stored at $-20^{\circ} \mathrm{C}$.

\section{Molecular Genetic Marker Analysis}

ISSR assays were performed as described by Lisek and Rozpara (2010), Fathi, et al., (2013), Ozyurt et.al.,(2013) and Khorshidi et.al,(2017).Six ISSR primers (Table 1) were selected from different published papers to be employed in ISSR analysis. SCOT amplification was performed as described by Xiong et al. (2011) and Guo et al.(,2012), using ten primers with 18-mer Sequence 5'- 3' (Table 1). These primers were selected from published papers Nair et.al.,(2016), Mohamed et.al.,(2017) and Dora et.al.,(2017).

Table (1): ISSR and SCoT primers used and their sequences.

\begin{tabular}{|c|c|c|c|}
\hline $\begin{array}{l}\text { ISSR } \\
\text { Primers }\end{array}$ & Sequence $5^{\prime}-3^{\prime}$ & $\begin{array}{l}\text { SCoT } \\
\text { Primers }\end{array}$ & Sequence 5' - 3' \\
\hline $14 \mathrm{~A}$ & CAGGCCCTTC & SCOT 1 & ACG ACA TGG CGA CCA CGC \\
\hline $89 A$ & GAAAGGGGTG & SCoT 2 & ACC ATG GCT ACC ACC GGC \\
\hline $44 B$ & GAAAGGGGTG & SCoT 3 & ACG ACA TGG CGA CCC ACA \\
\hline HB-12 & GTTGGTGGCT & SCOT 4 & ACC ATG GCT ACC ACC GCA \\
\hline HB-14 & GTA GACCCGT & SCOT 6 & CAA TGG CTA CCA CTA CAG \\
\hline \multirow[t]{5}{*}{ HB-15 } & GTGGTGGTGGC & SCOT 8 & ACA ATG GCT ACC ACT GAG \\
\hline & & SCoT 9 & ACA ATG GCT ACC ACT GCC \\
\hline & & SCoT 10 & ACA ATG GCT ACC ACC AGC \\
\hline & & SCoT 11 & ACA ATG GCT ACC ACT ACC \\
\hline & & SCoT 12 & CAA CAA TGG CTA CCA CCG \\
\hline
\end{tabular}




\section{Data Analysis}

The banding patterns generated by ISSR and SCOT were examined to determine the level of polymorphism and the genetic relatedness among the five seedy strains of Betulaefolia rootstock and four seedy strains of Mit-Ghamr rootstock treatments. The amplified fragments were scored as present (1) or absent (0), and were typed into computer file as a binary matrix. The matrix was then analyzed by PAST (free programs on web) software (Nei and Li, 1979).

\section{RESULTS AND DISCUSSION}

\section{I- Molecular genetic variability in Betulaefolia rootstock strains}

\section{1- ISSR-PCR molecular genetic markers:}

All the Betulaefolia rootstock strains recorded with ISSR primers (Plate1 and Table2 ), where they were visualized across 43 bands as a total number with molecular size from 255 to $1544 \mathrm{bp}$, the results obtained 32 total polymorphic bands at polymorphic percentage was $(74.44 \%)$ and the highest amplified polymorphic bands was (13 bands) its percentage was (92.8\%) produced with primer HB-14, while the lowest polymorphic percentage was $(42.8 \%)$ present with primer 14A, primer 89A has lowest number of monomorphic bands (4bands). On the other hand, the total results of monomorphic and specific marker bands were 11 and 13 in five primers respectively. There were some specific markers discriminated each cultivar from the others as indicated in table (2) where Primer 14A showed two specific markers for strains (stIV and stV)., Primer 89A showed one specific markers for (stV) strain, Primer HB-12 showed five specific markers, one of them for stV strain and the other four specific marker present with stIV strain. While, Primer HB-14 showed three specific marker one of them for (stII) and the other two specific markers were for (stIII). Also, Primer HB15 exhibited two markers for (stl). 


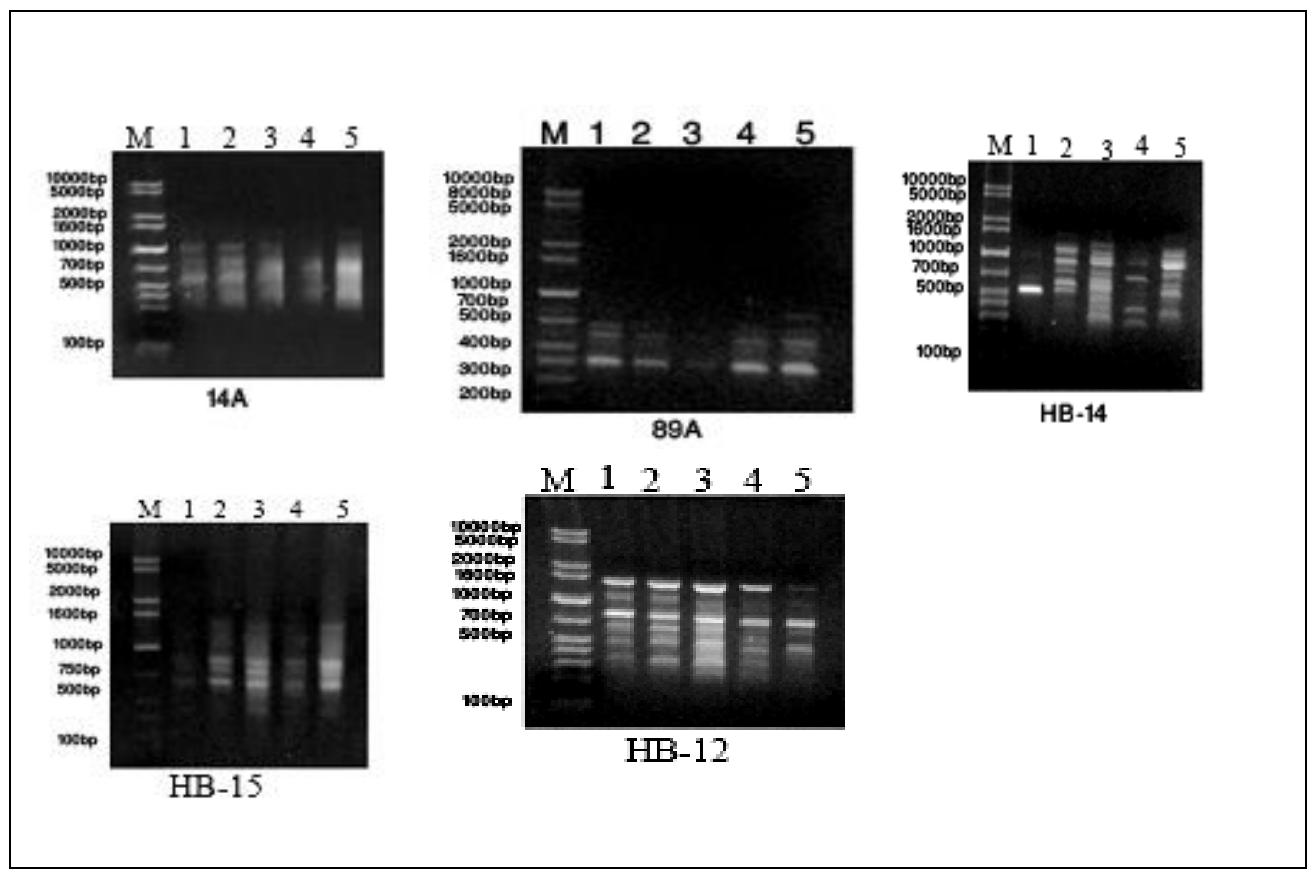

Plate(1): DNA polymorphism using ISSR-PCR for the five seedy strains(stl,stII,stIl,stIVand stV)of Betulaefolia rootstock amplified with five ISSR primers .

Table(2): List of ISSR primers of five seedy strains (stl,stll,stll,stIVand stV) of Betulaefolia rootstock. Percentage of polymorphism and Specific Marker bands (SM).

\begin{tabular}{lllllll}
\hline $\begin{array}{l}\text { Primer } \\
\text { Name }\end{array}$ & $\begin{array}{l}\text { Total } \\
\text { Bands }\end{array}$ & $\begin{array}{l}\text { M.size } \\
\text { range } \\
(\mathrm{bp})\end{array}$ & $\begin{array}{l}\text { Monomorphic } \\
\text { Bands }\end{array}$ & $\begin{array}{l}\text { Polymorphic } \\
\text { Bands }\end{array}$ & $\begin{array}{l}\text { Polymorphism } \\
\%\end{array}$ & $\begin{array}{l}\text { Specific } \\
\text { marker SM }\end{array}$ \\
\hline 14A & 7 & $\begin{array}{l}345- \\
1470\end{array}$ & 4 & 3 & $42.8 \%$ & $2(s t / V, s t V)$ \\
$89 A$ & 4 & $\begin{array}{l}315-730 \\
330-\end{array}$ & 2 & 2 & $50 \%$ & 1 (stIII) \\
HB-12 & 8 & $\begin{array}{l}1460 \\
255-\end{array}$ & 2 & 6 & $75 \%$ & $5(s t / V, s t V)$ \\
HB-14 & 14 & $\begin{array}{l}1510 \\
310-\end{array}$ & 1 & 13 & $92.8 \%$ & 3 (stII,stIII) \\
HB-15 & 10 & 1544 & 2 & 8 & $80 \%$ & 2 (stI) \\
\hline Total & 43 & $\begin{array}{l}255- \\
1544\end{array}$ & 11 & 32 & $74.44 \%$ & 13 \\
\hline
\end{tabular}




\section{2- SCOT-PCR molecular genetic markers}

Total number of bands was 62 with molecular size range (320 to 2000 bp) as represented in Plate (2) and Table (3). Five investigated rootstock strains were resulted from nine primers SCOT molecular genetic markers. The results obtained were 44 of total polymorphic bands with total polymorphic percentage (71\%), the highest polymorphic percentage was (88.9\%) produced with primer SCOT-9 and the lowest polymorphic percentage was (25\%) produced in case of primer SCoT-8. On the other hand, 18 monomorphic bands and seventeen specific marker bands in six primers were appeared. Finally, the highest total amplified bands (11bands) were recorded in case of primer SCoT-4 and SCoT-10 whereas, primer SCoT2 had the lowest amplified bands (3bands). The specific markers discriminated each strain from the others. Primer SCOT 2 showed one specific marker for strain (stII) and SCOT 3 showed three specific markers for the same strain. Primer SCOT 4 exhibited four specific markers for strain (stl). While, Primer SCoT 9 illustrated two specific markers one of them for (stIII) strain and the other specific marker for (stIV). Primer SCoT 10 exhibited four markers two for strains (stII) (stV) and the other two specific markers were for strain (stIV). Thus, it is clear that the highest specific markers was present with SCOT 4. 


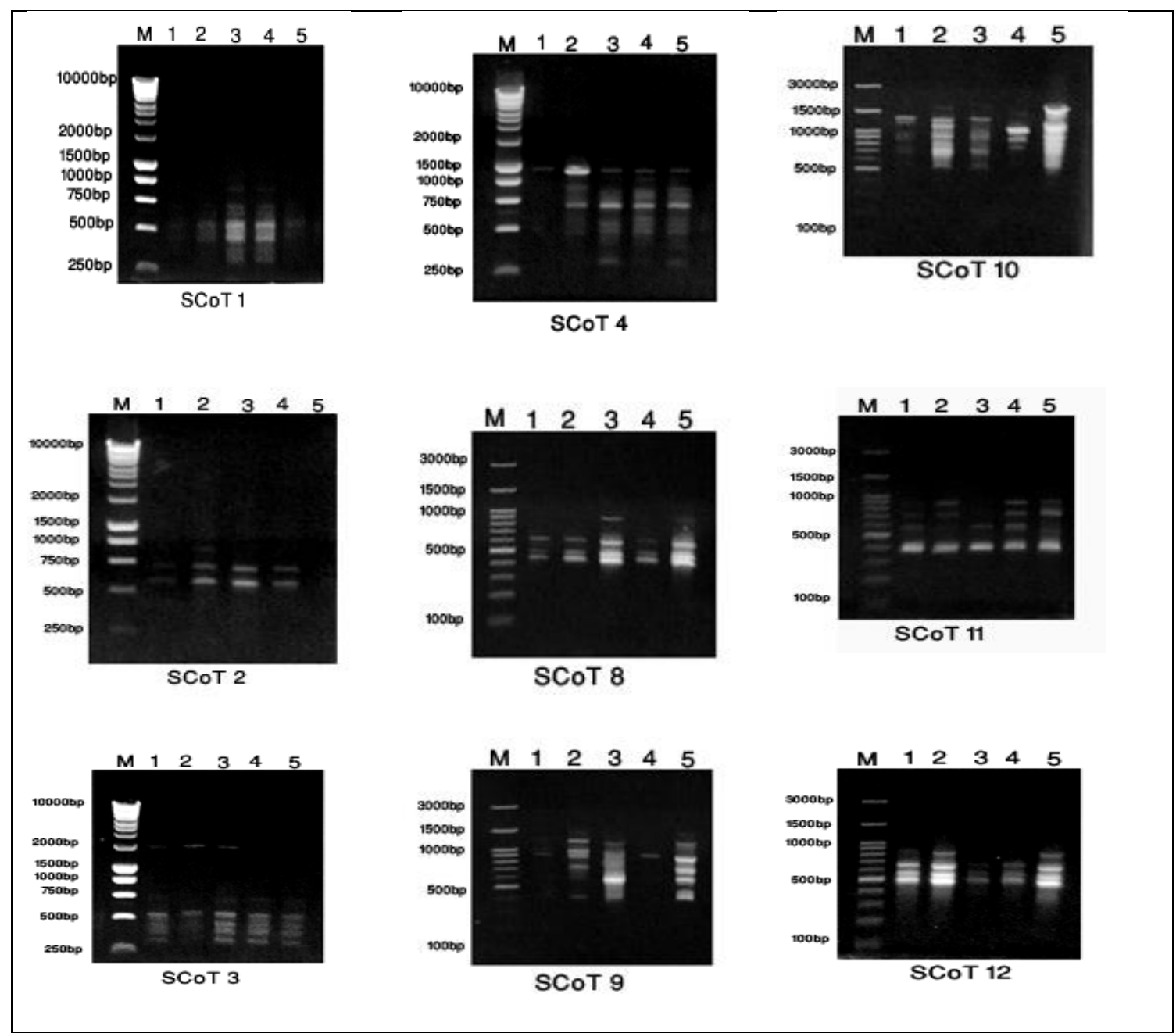

Plate(2): DNA polymorphism using SCoT-PCR for the five seedy strains of Betulaefolia rootstock amplified with nine SCOT primers.

Table(3):List of SCoT primers of five seedy strains of Betulaefolia rootstock. Percentage of polymorphism and Specific Marker bands (SM).

\begin{tabular}{c|c|c|c|c|c|c}
\hline $\begin{array}{c}\text { Primer } \\
\text { Name }\end{array}$ & $\begin{array}{c}\text { Total } \\
\text { Bands }\end{array}$ & $\begin{array}{c}\text { M. size } \\
\text { range } \\
(\mathrm{bp})\end{array}$ & $\begin{array}{c}\text { Monomorphic } \\
\text { Bands }\end{array}$ & $\begin{array}{c}\text { Polymorphic } \\
\text { Bands }\end{array}$ & $\begin{array}{c}\text { Polymorphism } \\
\%\end{array}$ & $\begin{array}{c}\text { Specific marker } \\
\text { SM }\end{array}$ \\
\hline SCoT-1 & 7 & $340-865$ & 2 & 5 & $71.4 \%$ & - \\
\hline SCoT-2 & 3 & $665-965$ & 2 & 1 & $33.3 \%$ & $1($ st II ) \\
\hline SCOT-3 & 6 & $320-2000$ & 2 & 4 & $66.7 \%$ & $3($ stll ) \\
\hline SCOT-4 & 11 & $345-1500$ & 2 & 9 & $81.8 \%$ & $4($ stl ) \\
\hline
\end{tabular}




\begin{tabular}{c|c|c|c|c|c|c}
\hline SCoT-8 & 4 & $455-915$ & 3 & 1 & $25 \%$ & - \\
\hline SCoT-9 & 9 & $425-1470$ & 1 & 8 & $88.9 \%$ & 2 (stIII,st/V) \\
\hline SCoT-10 & 11 & 5301680 & 2 & 9 & $81.8 \%$ & $4(s t I I, s t / V, s t V)$ \\
\hline SCoT-11 & 5 & $385-840$ & 2 & 3 & $60 \%$ & $3($ stII, stIII) \\
\hline SCoT-12 & 6 & $430-825$ & 2 & 4 & $66.7 \%$ & - \\
\hline Total & 62 & $320-2000$ & 18 & 44 & $71 \%$ & 17 \\
\hline
\end{tabular}

ISSR and SCOT Molecular genetic markers combination analysis

Resulted data of five seedy strains of Betulaefolia rootstock in table (4) clear that ISSR and SCoT primers recorded a sum (105 bands), these bands were identified as 29 monomorphic ones and 76 polymorphic bands with polymorphic percentage (72.38\%) and the polymorphic bands were scored as 30 specific markers.

Table (4): Polymorphic, Monomorphic, Specific Markers and Polymorphic percentage generated by the (ISSR and SCOT) analysis of five seedy strains of Betulaefolia rootstock.

\begin{tabular}{|c|c|c|c|c|c|}
\hline $\begin{array}{c}\text { Primers } \\
\text { Names }\end{array}$ & $\begin{array}{c}\text { Total } \\
\text { Band }\end{array}$ & $\begin{array}{c}\text { Monomorphic } \\
\text { Band }\end{array}$ & $\begin{array}{c}\text { Polymorphic } \\
\text { band }\end{array}$ & $\begin{array}{c}\text { Specific } \\
\text { Markers }\end{array}$ & $\begin{array}{c}\text { Polymorphic } \\
\%\end{array}$ \\
\hline ISSR & 43 & 11 & 32 & 13 & $74.44 \%$ \\
\hline SCoT & 62 & 18 & 44 & 17 & $71 \%$ \\
\hline Total & 105 & 29 & 76 & 30 & $72.38 \%$ \\
\hline
\end{tabular}

\section{II- Molecular genetic variability in Mit-Ghmar rootstock strains}

\section{1- ISSR-PCR molecular genetic markers}

All the examined five primers (Table 5 and plate 3) produced different ISSR-PCR banding patterns. The number of bands generated per primer varied between 5 was lowest amplified bands at $14 \mathrm{~A}$ and primer HB14 to 8 bands was the highest amplified bands at Primer 44B. Total number of 31 bands were visualized across the four investigated rootstock strains with molecular size ranging from 330 to $3460 \mathrm{bp}, 17$ of total polymorphic bands were scored with total polymorphic percentage $(54.8 \%)$, and the 
highest polymorphic percentage was $85.7 \%$ produced by primer HB-12, while the lowest polymorphic percentage was $20 \%$ illustrated with primers 14A and HB-14. On the other hand, total of 14 monomorphic bands were appeared and 13 specific marker bands in all five primers.

There were some specific markers discriminated each cultivar from the others as follows:-

Primer 14A showed one specific marker for strain (stl), Primer 44B showed three specific markers for (stIV) and four specific markers were produced from Primer HB-12 where three of them for( stl) strain and other specific marker was for (stIII) strain. While, Primer HB-14 exhibited one specific marker for (stIV) strain, and Primer HB-15 exhibited four specific markers, three of them were for (stl) strain and the other one for (st/V) strain. So, it is noted that specific marker in each 14A and HB-14 were the lowest number while the highest number of monomorphic Band was present at the same primers.

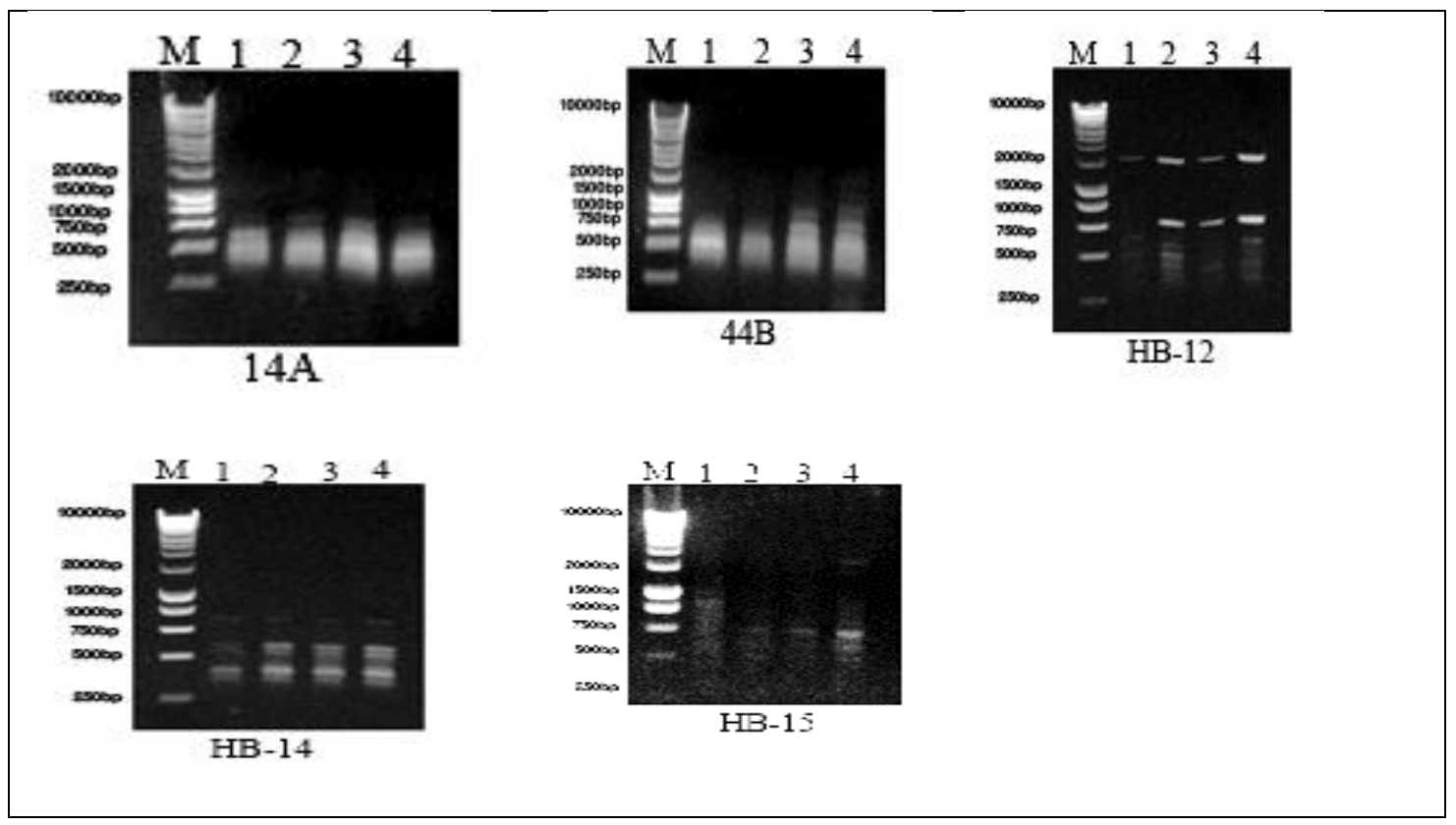

Plate(3):DNA polymorphism using ISSR-PCR for the four seedy strains of Mit- Ghamr peach rootstock amplified with five ISSR primers. 
Table(5):List of ISSR primers of four seedy strains of Mit- Ghamr peach rootstock. Percentage of polymorphic bands (PB) and Specific Marker bands (SM).

\begin{tabular}{|c|c|c|c|c|c|c|}
\hline $\begin{array}{l}\text { Primer } \\
\text { Name }\end{array}$ & $\begin{array}{l}\text { Total } \\
\text { Bands }\end{array}$ & $\begin{array}{c}\text { M. size } \\
\text { range } \\
\text { (bp) }\end{array}$ & $\begin{array}{c}\text { Monomorphic } \\
\text { Bands }\end{array}$ & $\begin{array}{c}\text { Polymorphic } \\
\text { Bands }\end{array}$ & $\begin{array}{c}\text { Polymorphism } \\
\%\end{array}$ & $\begin{array}{c}\text { Specific } \\
\text { marker } \\
\text { SM }\end{array}$ \\
\hline $14 \mathrm{~A}$ & 5 & $425-735$ & 4 & 1 & $20 \%$ & $1(s t l)$ \\
\hline $44 B$ & 8 & $330-1875$ & 3 & 5 & $62.5 \%$ & 3 (stIV) \\
\hline HB-12 & 7 & $365-2630$ & 1 & 6 & $85.7 \%$ & $4(s t l, s t I I I)$ \\
\hline HB-14 & 5 & $430-940$ & 4 & 1 & $20 \%$ & $1(s t / V)$ \\
\hline HB-15 & 6 & $480-3460$ & 2 & 4 & $66.7 \%$ & $4(s t I, s t I V)$ \\
\hline Total & 31 & $330-3460$ & 14 & 17 & $54.8 \%$ & 13 \\
\hline
\end{tabular}

\section{2- SCOT-PCR molecular genetic markers}

A high level of polymorphism was generated utilizing the nine SCOTPCR primers (Plate 4 and Table 6) represent a total number of 66 bands were visualized across the four investigated rootstock strains with molecular weights ranging from 185 to $1480 \mathrm{bp}$. Total amplified bands were 37 with polymorphic percent $(56.1 \%)$ and the highest polymorphic percentage recorded at (77.8\%) with primer SCOT-9. No polymorphic percentage was produced with primer SCOT-12. On the other hand, total monomorphic bands appeared 29, where twenty-seven specific marker bands present in eight primers. Finally, Primer SCOT-3 showed the highest amplified bands (twelve bands) whereas, primer SCOT- 8 and primer SCOT-12 were the lowest amplified bands (four bands).

Primer SCoT1 exhibited two specific markers for strain (st.l) and (st. IV). On the other hand, Primer SCOT 3 showed six specific markers, one for each (stl and stIV) and two specific markers for two strains (stll and stIII). 
Four specific markers were resulted from primer SCoT 4 and all of them for (stl) strain. In case of Primer SCoT 6 two specific markers one of them for (stII) strain and the other was for (stIV) strain. In the same way, primer SCot 8 produced one specific marker for (stIV) strain and four specific marker for (stl) strain exhibited with primer SCOT 9. While, primer SCOT 10 produced four specific markers, three of them found in (stl) strain and the other one for (stIII) strain and four specific markers were illustrated from primer SCOT 11 , where three of them for (stIII) strain and the other one for (stII).

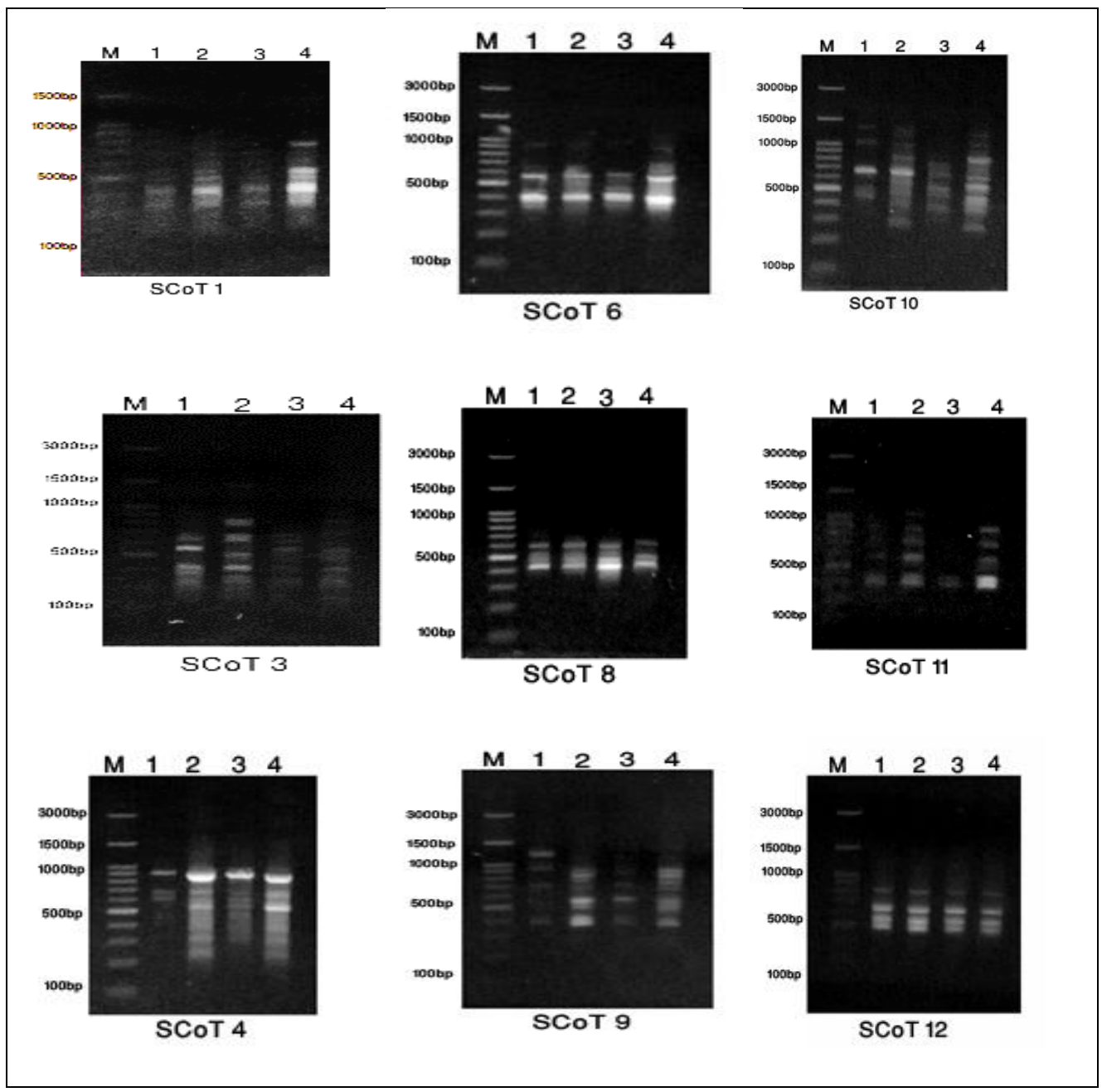

Plate (4): DNA polymorphism using SCoT-PCR for the four seedy strains of Mit-Ghamr peach rootstock amplified with nine SCoT primers. 
Table (6): List of SCOT primers of four seedy strains of Mit- Ghamr peach rootstock. Percentage of polymorphic bands (PB) and Specific Marker bands (SM).

\begin{tabular}{|c|c|c|c|c|c|c|}
\hline $\begin{array}{l}\text { Primer } \\
\text { Name }\end{array}$ & $\begin{array}{l}\text { Total } \\
\text { Bands }\end{array}$ & $\begin{array}{c}\text { M.size } \\
\text { range } \\
\text { (bp) }\end{array}$ & $\begin{array}{c}\text { Monomorphic } \\
\text { Bands }\end{array}$ & $\begin{array}{c}\text { Polymorphic } \\
\text { Bands }\end{array}$ & $\begin{array}{c}\text { polymorphism } \\
\%\end{array}$ & $\begin{array}{c}\text { Specific } \\
\text { marker SM }\end{array}$ \\
\hline SCoT-1 & 7 & $335-770$ & 5 & 2 & $28.6 \%$ & $2(s t l, s t I V)$ \\
\hline SCOT-3 & 12 & $185-1480$ & 5 & 7 & $58.3 \%$ & $\begin{array}{l}6(s t l, s t I I, \\
s t I I I, s t I V)\end{array}$ \\
\hline SCoT-4 & 7 & 245-935 & 2 & 5 & $71.4 \%$ & $4(s t l)$ \\
\hline SCoT-6 & 6 & $350-925$ & 3 & 3 & $50 \%$ & $2(s t I I, s t / V)$ \\
\hline SCoT-8 & 4 & $435-610$ & 3 & 1 & $25 \%$ & 1 (stIV) \\
\hline SCOT-9 & 9 & $400-1270$ & 2 & 7 & $77.8 \%$ & $4(s t l)$ \\
\hline SCoT-10 & 11 & $285-1380$ & 3 & 8 & $72.7 \%$ & $4(s t l, s t I I I)$ \\
\hline SCoT-11 & 6 & $385-1070$ & 2 & 4 & $66.7 \%$ & $4(s t I I, s t I I I)$ \\
\hline SCoT-12 & 4 & $500-815$ & 4 & - & - & - \\
\hline Total & 66 & $185-1480$ & 29 & 37 & $56.1 \%$ & 27 \\
\hline
\end{tabular}

ISSR and SCOT Molecular genetic markers combination analysis

Table (7) illustrate combination data of ISSR and SCOT primers for four seedy strains of peach Mit-Ghamr rootstock, where produced 97 bands as a total bands, these bands were identified as 43 monomorphic ones and 54 polymorphic bands with polymorphic percentage $(55.6 \%)$ and 40 specific markers.

Table (7): Polymorphic, Monomorphic, Specific Markers and Polymorphic $\%$ generated by the (ISSR and SCOT) analysis four seedy strains of MitGhamr rootstock.

\begin{tabular}{|l|l|l|l|l|l|}
\hline $\begin{array}{l}\text { Primers } \\
\text { Names }\end{array}$ & $\begin{array}{l}\text { Total } \\
\text { Band }\end{array}$ & $\begin{array}{l}\text { Monomorphic } \\
\text { Band }\end{array}$ & $\begin{array}{l}\text { Polymorphic } \\
\text { band }\end{array}$ & $\begin{array}{l}\text { Specific } \\
\text { Markers }\end{array}$ & $\begin{array}{l}\text { Polymorphic } \\
\%\end{array}$ \\
\hline ISSR & 31 & 14 & 17 & 13 & $54.8 \%$ \\
\hline SCoT & 66 & 29 & 37 & 27 & $56 \%$ \\
\hline Total & 97 & 43 & 54 & 40 & $55.67 \%$ \\
\hline
\end{tabular}


General the results indicated that ISSR and SCOT analysis possible use to detect molecular genetic variability in seedy strains of Betulaefolia and MitGhamr peach Rootstocks and characteristic Marker Assisted Selection (MAS) for detect biotic and a biotic stress for these strains and we can obtain a new fruit rootstocks tolerance to salinity and drought and other different a biotic stress.

Conclusion, all ISSR and SCOT primers used in the present study allowed for enough distinction among the five seedy strains of Betulaefolia and four seedy strains of Mit-Ghamr Rootstocks. Overall comparison among seedy rootstocks across the used primers revealed the power of studied molecular genetic markers in distinguishing genetic variability between strains of seedy deciduous fruit rootstocks grown in the same location and these results were in line with Mohamed et al., (2015), Khorshidi et.al,(2017), Shahlaei et.al.,(2014), Etminan et. al, (2016) and Nair et.al.,(2016).

\section{REFERENCES}

Abo Rekab, Z. A.M.; E.G. Gadalla and S.Y. Mohamed (2010). Physiological and molecular genetic evaluation of the most important Egyptian dry Date Palm. J. Biol. Chem. Environ. Sci.,5(3): 23-47.

Amirmoradi, B.;R and Karami, E. (2012): Comparison of genetic variation and differentiation among annual Cicer species using start codon targeted (SCOT) polymorphism, DAMD-PCR, and ISSR markers. Plant Systematics and Evolution. 298(9):1679-1689.

Dora,S.A ; Mansour M. ; Aboulila A. A. and Abdelwahab E. (2017): Genetic diversity and relationships among some barley genotypes for net blotch disease resistance using RAPD, SCOT and SSR markers. Egypt. J. Genet. Cytol. , 46: 139-165.

Etminan, A ; Pour-Aboughadareh A.; Mohammadi R. ; Ahmadi R. A.; Noori A.; Mahdavian Z. and Moradi Z. (2016): Applicability of start codon targeted (SCOT) and inter-simple sequence repeat (ISSR) markers for genetic diversity 
analysis in durum wheat genotypes. BIOTECHNOLOGY \& BIOTECHNOLOGICAL EQUIPMENT.,30(6) :1075-1081 .

Fathi, M.A.; Hussein SH. M. and Mohamed S.Y. (2013) : Horticultural And Molecular Genetic Evaluation Of Some Peach Selected Strains Cultivated Under Kalubiah Governorate Conditions. J Am Sci., 9(1s):12-23.

Gad, M.A and Mohamed S.Y.(2012): Phylogenetic evaluation of some Pinus species from different genetic resources using protein isozyme, RAPD and ISSR analysis. Journal of American Science.,8 (3) : 311-321.

Gihan; H.S.; Mervat. S. and Mohamed S.Y. (2009): Horticulture and Molecular Genetic Characterization of Some Grape Cultivars under Desert Land Conditions. J. Biol. Chem. Environ. Sci., 4(1):519-544.

Gorji A.M., Poczai P. , Polgar Z. and Taller J. (2011) : Efficiency of arbitrarily amplified dominant markers (SCOT, ISSR and RAPD) for diagnostic fingerprinting in tetraploid potato. Am J Potato Res., 88:226-237.

Guo, D.L ; Zhang J.Y. and Liu C.H. (2012): Genetic diversity in some grape varieties revealed by SCoT analyses. Mol. Biol. Rep., 39:5307-5313.

Khorshidi,S· ; Davarynejad G. ; Samiei L. and Moghaddam M. (2017): Study of Genetic Diversity of Pear Genotypes and Cultivars (Pyrus communis L.) using Inter-Simple Sequence Repeat Markers (ISSR). ErwerbsObstbau.,59: 301-308.

Lisek A., and Rozpara E. (2010): Identification of pear cultivars with RAPD and ISSR markers. J Fruit Ornam Plant Res., 18(2):17-22.

Mohamed A.S.H.; Ibrahim M. ; Teleb S.S. ; Tantawy M.E. (2017). SEM and SCoT Markers Unveil New Taxonomic and Genetic Insights about Some Northern African Triticum aestivum L. Cultivars. Vegetos 30:1. 
Mohamed, S.Y and El-Sharabasy S. F. (2009): Molecular genetic evaluation of some Date Palm cultivars (Phoenix Dactylfera L.) in Egypt. Egypt. J. Biotechnol., 33:167-181.

Mohamed, S.Y.; Shoaib R.M. and Gadalla N.O. (2015): Selection Some Seedling Apricot Strains At Al-Amar Region. Journal of Applied Science., 15(2) :192-204.

Nair, A. G H; Vidya P., and Mohan C. (2016): Analysis of genetic variability in sweet potato accessions using Start Codon Targeted (SCOT) polymorphism. International Journal of Biotechnology and Biochemistry.,12 (2) : 111-121.

Nei, M, and Li W. H. (1979): "Mathematical Model for Studying Genetic Variation in Terms of Restriction Endonucleases." Proceedings of the National Academy of Sciences of the United States of America., 76(10): 5269-5273.

Ozyurt, I. K; Akca Y. and Ercisli S. (2013): Molecular characterization of Prunus mahaleb L. rootstock canditates by ISSR markers. Genetika,45 (3) :717-726.

Shahlaei, A.; Torabi S. and Khosroshahli M. (2014): Efficiacy of SCOT and ISSR marekers in assesment of tomato (Lycopersicum esculentum Mill.) genetic diversity. Int. J. Biosci. International Journal of Biosciences, 5 (2) :1422.

Xiong F; Zhong R. ; Han Z.; Jiang J. ; He L. ; Zhuang W.S and Tang R. (2011): Start codon targeted polymorphism for evaluation of functional genetic variation and relationships in cultivated peanut (Arachis hypogaea L.) varieties. Mol Biol. Rep., 38(5):3487-3494.

\section{https://www.rosaceae.org/organism/Prunus/persica}


التباين الوراثى الجزيئى لبعض أصول الفاكهة المتساقطة فى مصر

صفاء محمد صالح' - نهلة عثمان احسان' - سيد يوسف محمد' ـ ثريا رشاد محمد'

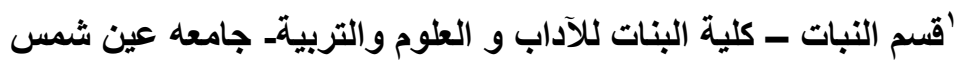

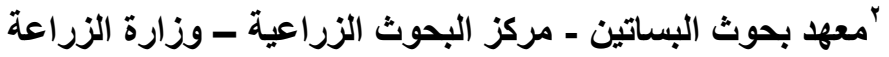

أجريت هذه الدر اسة بمزرعة قسم بحوث الفاكهة المتساقطة وبمعمل البيوتكنولوجي -

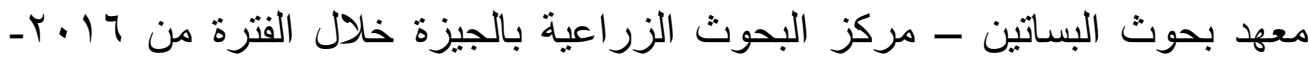

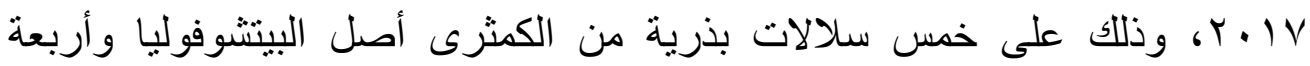

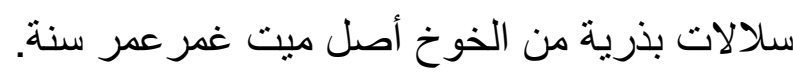

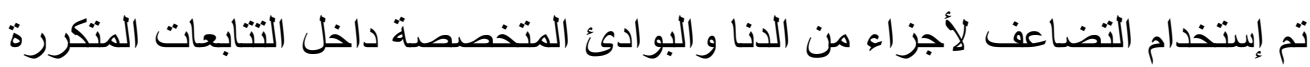
بإستخدام جهاز تفاعل سلسلة البلمرة (SSSR-PCR) و (SCOT-PCR) لتقدير التباين

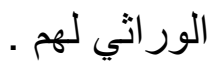
نجحت ستة بوادئ SSSR و عشرة بو ادئ SCOT مع السلالات البذرية الخمسة من الكثثر والسلالات البذرية الاربعة من الخوخ في اظهار مستويات عالية من التباين الور اثي.

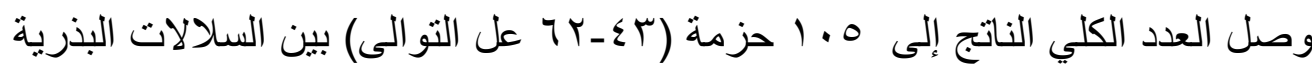

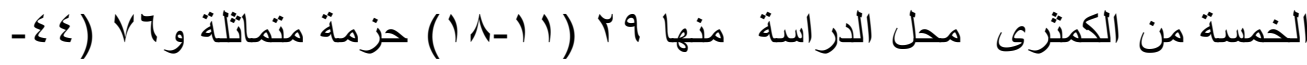

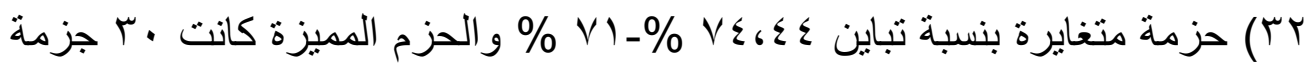

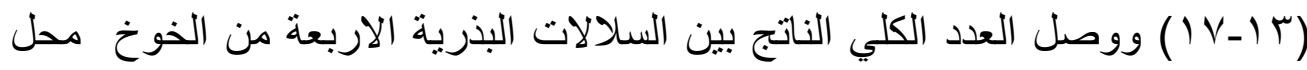

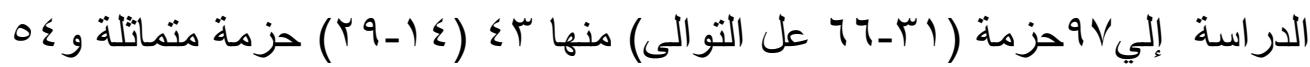
(IV_rV) جزمة (rV-IT) 
